\title{
Interactions: Trade Policy and Healthcare Reform After Chaoulliv. Quebec
}

\section{Interactions : les politiques commerciales et la réforme des soins de santé après Chaoulli c. Québec}

Is it time for Canada to acknowledge the fragile boundary between bealth and trade policies and strengthen the separation between private and public health insurance?

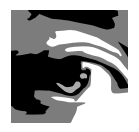

by MARK CRAWFORD, LLB, DPHIL

Lecturer, Department of Political Science University of Northern British Columbia

Prince George, $B C$

\begin{abstract}
The insulation of Canada's healthcare system from trade treaty obligations is crucial to the legitimacy of Canada's trade policy. Legal analysis has suggested, however, that competitive and for-profit delivery of the kind contemplated by the Kirby Report and some provinces may make healthcare more vulnerable to challenges under NAFTA and GATS. The Government of Canada has tried to counter this interpretation by stressing the importance of public financing as the principal criterion for exemption of healthcare from trade treaties, but now the potential for private financing of essential medical services indicated by the Supreme Court's decision in Chaoulli v. Quebec has made that line of argument look risky as well. It is apparent that Canada failed to anticipate the possible interactions of domestic, international and constitutional
\end{abstract}


law when it made commitments in the area of private health insurance at the WTO in 1997. Accordingly, the time has come to acknowledge the fragility of the boundary between health and trade policies, to take the risks and costs associated with trade treaty obligations fully into account when undertaking healthcare reform and to strengthen the separation between private and public health insurance.

\section{Résumé}

L'isolation du système de soins de santé canadien par rapport aux accords commerciaux est essentielle à la légitimité des politiques commerciales du Canada. Les analyses juridiques ont suggéré, cependant, que la prestation concurrentielle et à but lucratif envisagée dans le rapport Kirby et par certaines provinces peut rendre les soins de santé plus vulnérables à des défis sous l'ALÉNA et l'AGCS. Le gouvernement canadien a essayé de contredire cette interprétation en insistant sur l'importance du financement public comme principal critère pour soustraire les soins de santé aux accords commerciaux; mais maintenant la possibilité de financer les services médicaux essentiels avec des fonds privés, tel qu'indiqué par la décision de la Cour suprême dans l'affaire Chaoulli c. Québec, fait paraître cet argument un peu risqué également. Il appert que le Canada a mal anticipé les interactions possibles entre le droit national, international et constitutionnel lorsqu'il a pris des engagements envers l'OMC en matière d'assurance-santé privée en 1997. Le temps est donc venu de reconnaître la fragilité de la frontière entre les politiques de santé et les politiques commerciales, de tenir pleinement compte des risques et des coûts associés aux engagements pris dans le cadre des accords commerciaux lorsqu'on entreprend une réforme des soins de santé, et de renforcer la séparation entre l'assurance-santé publique et privée.

He advent of the North American Free Trade Agreement
(NAFTA) and the World Trade Organization's General Agreement on
Trade in Services (GATS) raised concerns about whether and to what extent NAFTA and GATS obligations might apply to Canada's health sector. Many observers have agreed that, generally speaking, it appears unlikely that most medically necessary services provided through public health insurance in Canada fall within the scope of either NAFTA or GATS, in large part because the "public" nature of Canada's healthcare financing is a more important factor in determining the scope of exemptions from trade treaty obligations than the primarily "private" nature of Canada's healthcare delivery (i.e., the use of private for-profit and not-for-profit actors and institutions to organize, manage and provide health services) (Epps and Flood 2002; Van Duzer 2004b; Crawford 2005). 
The recent trend towards market-based reform proposals, most of which experiment with competitive models of delivery as a way to improve efficiency and sustainability of the system, has raised new questions about the risk that Canada will incur trade treaty obligations that could constrain future policy options. The Government of Canada and other defenders of Canada's participation in NAFTA and GATS have argued that this risk is acceptably small, relying once again on the crucial distinction between financing and delivery (Deber 2002): how healthcare is paid for (i.e., whether hospital and physician services under medicare are paid for through public or private insurance) is the point that matters most in developing legal tests for NAFTA and GATS obligations (DFAIT 2005).

The Supreme Court decision in Chaoulliv. Attorney-General (Quebec) - a case that struck down a Quebec law prohibiting private health insurance for publicly insured hospital and physician services - is about financing. As Quebec and other provinces consider their options in terms of introducing private health insurance to cover physician and hospital services, we must carefully re-examine the relationships between trade treaties, proposals for healthcare reform and the insurance market. This paper contributes to that discussion by investigating two questions in the light of the Chaoulli decision: first, whether the present degree of insulation of public healthcare from trade treaty obligations can be maintained in the face of growing pressures for liberalization, both inside and outside the healthcare system; and second, what policy options can best restore and secure the balance between trade and health policy in the future.

\section{The Scope of Chaoulli and Its Significance for the Interface Between Trade Policy and Healthcare Reform}

In Chaoulli, the Supreme Court of Canada decided in a narrow 4-3 judgment to invalidate Quebec's prohibition against the sale of private insurance for core medical services provided through medicare on the grounds that it violated the guarantee of rights "to life and to personal inviolability" in Quebec's Charter of Human Rights and Freedoms (s. 1). Although Deschamps J. noted in the majority judgment that section 1 of the Quebec Charter is broader in scope than the equivalent section of the Canadian Charter of Rights and Freedoms, three of the concurring justices (Chief Justice McLachlin, Justice Major and Justice Bastarache) also found Quebec's ban to be in contravention of the guarantee of "life, liberty and security of the person" contained in section 7 of the Canadian Charter of Rights and Freedoms. While the McLachlin/ Major judgment allows that the prohibition on obtaining private health insurance "might be constitutional in circumstances where healthcare services are reasonable as to both quality and timeliness," it leaves open the possibility for challenges to even less restrictive legislation aimed at promoting the single-payer principle (such as the 
measures in Ontario, Nova Scotia and Manitoba that prevent physicians from charging more privately than they would receive in the public plan) if such laws are found to have prevented certain individuals from gaining timely access to medical treatment (Flood and Lewis 2005).

In contrast, the dissenting minority judgment of Justices Binne, LeBel and Fish found that the "debate [about whether government ought to discourage a second private tier of healthcare] cannot be resolved as a matter of constitutional law by judges." Noting that the Quebec health plan shared the health policy objectives of the Canada Health Act, i.e., that Quebec wanted a health system where access is governed by need rather than by wealth or status, the dissenting justices were unprepared to pre-empt an ongoing public debate over fundamental social policy in the absence of a clear violation of an established principle of fundamental justice. In their view, even the broader wording of the Quebec Charter could not justify striking down the law, in the light of that Charter's requirement that rights be exercised with "proper regard" to "democratic values, public order and the general well-being of the citizens of Québec."

While couched in the language of constitutional interpretation, the dissent expressed the more general standpoint of critics of judicial activism in matters of complex social policy: "Designing, financing and operating the public health system of a modern democratic society remains a challenging task and calls for difficult choices. ... Shifting the design of the health system to the courts is not a wise outcome" (Chaoulli 2005: para. 276). Some critics of the Chaoulli decision who believe in the appropriateness of political solutions to the problem of waiting lists in the healthcare system may advocate that Canadian governments be prepared to use the Canadian Charter's section 33 (the "notwithstanding" clause) in response to the Chaoulli ruling (Evans 2005). This would permit Parliament to override the effect of the ruling for five years before it would be reviewed again.

Although it is seldom remarked upon, the ban on private health insurance has also been a fundamental assumption of Canada's trade policy ever since NAFTA and GATS took effect over a decade ago. That is because, in order to assure Canadians that the expansion of trade liberalization to include services would not adversely affect our healthcare system, while at the same time assuring the Canadian life and health insurance industry that it could gain more secure access to foreign markets through trade agreements, public insurance and private insurance were sharply distinguished. Public insurance was delineated as financing medically necessary physician and hospital services through provincial health plans. Private insurance was strictly reserved for services that, whatever their status in other countries, are "supplemental" to the core of medicare in Canada and are not publicly funded. This complete separation between public and private insurance appears to have been taken for granted by Canadian governments, which negotiated specific commitments for financial services under GATS and made no attempt to exclude private health insurance from the terms of NAFTA. 


\section{Is Healthcare Really "Off the Table" in International Trade Negotiations?}

The two major principles that have been developed as essential to the long-term achievement of trade liberalization are the most-favoured-nation principle (MFN), or external non-discrimination by a member country among its foreign trading partners, and the national treatment principle, or non-discrimination between foreign and domestic interests inside a member country. If MFN were applied to a service in the healthcare sector, the degree of access to the Canadian market afforded to that service imported from one "most-favoured" trading partner would have to be extended to all other trading partners who are parties to the same trade agreement. (Conversely, Canadian healthcare exporters of that service would be entitled to the same degree of access to the market of any other signatory country as that country's most-favoured partner.)

This obligation would not necessarily be onerous or highly disruptive of our healthcare system because it does not require that we open our markets to foreign suppliers, only that we not discriminate among those suppliers when we do. However, if governments experiment with private insurance, subsequently change their mind and wish to return to the present status quo, this policy switch may be thwarted by the prospect of having to compensate foreign suppliers who lose business access as a result.

The effects of the national treatment could be potentially even more intrusive and less consistent with the principles governing our existing healthcare system. The principle requires that foreign suppliers of a particular health service be given the same commercial opportunities as domestic suppliers. For example, applying national treatment to hospital services could force Canadian hospitals to compete with foreign corporate for-profit hospital chains, a possibility that could have far-reaching consequences for the nature of the service.

If by "medicare" we mean the two major publicly funded programs of hospital services and physician services (Evans 2003), then we may state that it has not yet been subjected to either MFN or national treatment obligations. Nevertheless, when the complex and changing nature of healthcare services funding and delivery is combined with the broad and largely untested scope of GATS and NAFTA rules, there is also bound to be a large penumbra of uncertainty surrounding the application of those rules. Estimating healthcare's insulation from trade treaties is therefore a probabilistic, not a categorical, exercise (Crawford 2005).

The task is further complicated by the very different architectures of NAFTA and the WTO/GATS. Under NAFTA, which is principally a "top-down" agreement that imposes its obligations except where expressly exempted, reservation clauses are the most important instrument for shielding public healthcare. The most serious concern raised by NAFTA for healthcare policy is whether changes in the domestic policy 
environment - such as the expansion of private health insurance, changes in the scope of the public system or even the expansion of for-profit delivery - might cause important, medically necessary services to be no longer shielded from national treatment, MFN or other NAFTA obligations. This exposure could in turn lead to NAFTA claims for financial compensation by US or Mexican private investors if governments tried to establish or re-establish a public monopoly. Under GATS, which is primarily a "bottom-up" agreement, national treatment and associated market access obligations apply only when countries choose to list them in their schedules of specific commitments. (A special exemption clause for services "supplied in the exercise of governmental authority" also exists to protect certain public services from being covered by the more generally applicable GATS MFN and transparency obligations.) Failure to meet these obligations could lead to a claim by governments of affected service suppliers and an award by a WTO dispute panel of compensation in the form of trade concessions to those countries.

It might seem a simple matter to avoid making any such commitments that could affect medicare, but in practice it is proving to be more difficult. In particular, the supply of private health insurance was classified for GATS purposes as a "financial service," an area in which Canada has a comparative advantage and has been aggressive in seeking reciprocal commitments. Insurance exports rose from $\$ 1.957$ billion annually to $\$ 3.067$ billion between 1990 and 2001, and imports from $\$ 2.238$ billion to $\$ 4.462$ billion. Like other knowledge-intensive commercial services, this industry is an important source of Canadian competitiveness and high-paying jobs. It is thus not surprising that Canada has continued to make offers in this sector in the WTO's Doha round of negotiations since 2001, including an offer in 2003 of commitments to open foreign bank entry, to ease foreign ownership restrictions and to improve transparency of financial regulations. It now appears in the wake of Chaoulli, however, that the Canadian government failed to anticipate the possible repercussions of making commitments with respect to market access and national treatment in the area of private health insurance when it concluded the Financial Services Agreement along with 103 other WTO members in 1997.

\section{NAFTA Reservations and Healthcare}

NAFTA is a large document, running over a thousand pages, which, in addition to liberalizing trade in goods between Canada, the United States and Mexico (virtually all trade in the NAFTA region has flowed tariff-free since 2003), has helped break new ground in such areas as government procurement, investment, services trade, intellectual property and dispute settlement. Investment was a key item on the US agenda in its negotiations with both Canada (in the earlier Canada-US Free Trade Agreement) and Mexico. Chapter 11 (investment) extends national treatment and 
MFN rules to the establishment of new businesses, raises the threshold for the review of foreign direct investment by the Canadian government and states that the expropriation of businesses can occur only for a "public purpose," on a non-discriminatory basis and for financial compensation at "fair market value." Chapter 12 (services) contains similar provisions imposing national treatment and MFN obligations on each country's policies towards service providers, although it does contain (in Article 1201) a provision that nothing in the agreement shall be construed to prevent a party from providing such services as social welfare, public education, health and child care. Both of these chapters are also explicitly subject to reservations and exceptions set out in each country's schedule to Annex I.

The view that the scope of NAFTA reservations in relation to health services is sufficient to protect publicly funded healthcare in Canada from any NAFTA challenge is a reasonable interpretation from a static perspective, based upon the accepted definitions of public and private health services at the time of NAFTA's inception (Epps and Flood 2002; Van Duzer 2004a). Canada's Annex I Reservation states that all provincial government measures that were in force as of January 1, 1994 are outside NAFTA rules relating to national treatment, MFN and some other disciplines relating to local-presence requirements for cross-border services and nationality requirements for senior managers. Laws, measures or amendments thereto subsequent to January 1, 1994 that exclude or otherwise discriminate against US and Mexican providers of services are contrary to NAFTA, unless they are saved by the Annex II Social Service Reservation.

Under Annex II of NAFTA, each party reserved the right to adopt or maintain any measure relating to health services that may be characterized a "social service established or maintained for a public purpose." The precise scope of this Social Service Reservation is the subject of much debate and speculation. The US Trade Representative in 1995 suggested that the reservation is intended to cover only services that "are similar to those provided by government, such as childcare or drug treatment programs"; if those services are supplied by a private firm on a profit or nonprofit basis, chapters 11 (investment) and 12 (services) would apply. The Canadian government has claimed that, to the contrary, NAFTA panels should look at the government's intent in determining whether a service is "established or maintained for a public purpose." Legal academics generally agree that an objective test based on general criteria for what constitutes a public service is necessary. Where full state funding is combined with extensive government control over delivery, then there is a very strong case for the application of the reservation. It is probable (though by no means certain) that full state funding alone is sufficient, even where governments permit competition and for-profit delivery in the interests of efficiency (Epps and Flood 2002).

Accordingly, the fact that insured services are designated by a provincial government as "medically necessary" and are paid for by a public authority is a good indica- 
tion that such services fall within Annex II and thus outside NAFTA.

If governments choose to respond to the Chaoulli decision by allowing the growth of private insurance to cover services that are presently publicly insured (medically necessary hospital and physician services), then the condition of government-funded monopoly will disappear. It is already apparent that the Social Service Reservation does not protect measures related to for-profit, privately funded services of physicians and other healthcare professionals, or privately funded home care or nursing home services (Van Duzer 2004a). It is very likely that allowing private insurance for services designated as "medically necessary" would further reduce the scope of this NAFTA reservation (Epps and Schneiderman 2005).

\section{GATS “Governmental Authority” Exclusion}

Canada's GATS obligations present a similar picture of current insulation of healthcare coupled with increasing future vulnerability to coverage (Van Duzer 2004b; Crawford 2005). GATS contains an exemption from the most basic MFN and transparency obligations for services "supplied in the exercise of governmental authority," which are defined in Article I:3 as any service that is "supplied neither on a commercial basis, nor in competition with one or more service suppliers." The legal meaning of "competition" probably involves consumers' ability to choose between "like" services offered by different suppliers, but it is unclear, even if services are fully publicly funded and competition is tightly regulated, whether the system would still meet the GATS criterion. There seems to be little doubt, however, that the introduction of private competition on the financing side would guarantee that the service being supplied would fall outside the Article I:3 exclusion. Similarly, any finding of supply to be "on a commercial basis" would need to consider a range of criteria: whether a service is supplied on a for-profit basis; whether user fees are charged; whether any revenues earned in excess of cost are devoted to fulfillment of a not-for-profit purpose; and the degree of government involvement and control over conditions of service delivery. Most of these criteria, when applied to core medical services as they are currently supplied in Canada, would not indicate their classification as being supplied "on a commercial basis" (Krajewski 2003; Van Duzer 2004b; Crawford 2005).

In its response to J. Anthony Van Duzer's (2004b) report, Health, Education and Social Services in Canada: The Impact of the GATS, the government agreed with most of these conclusions, except that it questioned whether "degree of government involvement is a determinant of whether or not a service is provided on a commercial basis" and argued that a wider range of services, such as physician services operating outside of hospitals, would fall within the scope of "governmental authority" (DFAIT 2005). It is not surprising that the Government of Canada would put forward a slightly broader interpretation of the GATS exclusion clause than that of GATS critics or 
most of the leading legal academic opinions. The crucial point is that the federal government's emphasis on public funding as the criterion for what is excluded from GATS coverage helps to downplay the risk that expansion of publicly funded and privately delivered healthcare or Kirby-style reforms (i.e., experiments with competitive, private for-profit or not-for-profit delivery) (Standing Committee on Social Affairs, Science and Technology 2002) will incur those obligations. But the government's reliance and emphasis on protections being sourced in the extent of public funding clearly exposes the dangers that arise from allowing inroads from private insurance and other forms of financing.

\section{Specific GATS Commitments: The Scope of National Treatment and Market Access Obligations}

The most onerous WTO/GATS obligations are those that are incurred through commitments to accept national treatment and market access obligations in specific sectors. A look at Canada's Schedule of Specific Commitments shows that Canada has avoided undertaking obligations in respect of "health and public education," consistent with its pronouncements. There is one notable and worrisome exception: private insurance, such as Blue Cross, is categorized as a "financial service" for WTO/ GATS purposes, just as it is for NAFTA purposes. Canada in 1997 made a commitment in "life, accident and health insurance services," subject only to the limitation on market access that these services "must be supplied through a commercial presence" (i.e., through direct investment and establishment within Canada).

Some critics and health policy advocates have worried that public health insurance is possibly already covered under Canada's GATS commitments on financial services (Sanger 2001). In response, the Government of Canada has maintained that Canada's commitments with respect to "health insurance services" are clearly restricted to supplemental health insurance services provided by private insurers, since GATS excludes governmental services that are not "in competition with one or more service suppliers." Technically, the government has probably been right, at least to date - the distinction between public and private health insurance is likely to be recognized by WTO dispute panels because medicare is not insurance in the same sense as private life insurance or other financial services. The main threat of a trade challenge stems from compensation claims created by the expansion of medicare into territory previously occupied by private insurers, not from a failure to enter specific limitations that would shield existing provincial public health insurance plans from GATS commitments or a misplaced faith in a narrow Article I:3 exclusion clause (Van Duzer 2004b: n. 5, 417-425).

But now there is Chaoulli, and all the old conclusions and safe harbours must be 
revisited. The assumption that medically necessary services are "public" and that supplemental insurance is "private" - that the two areas of insurance are mutually exclusive - clearly underpinned the government's decision to make commitments in private health insurance in the first place. If Canada's public health insurance plans are forced by judicial decisions into competition with private suppliers, then that fundamental assumption no longer obtains and the worries of GATS critics over medicare's vulnerability to GATS obligations will be warranted. In response to the question,"Will GATS commitments for private insurance prevent Canada from expanding medicare?," the Government of Canada has stated on its website that "foreign firms represent a minority of the private health insurance market," that "private insurers could lose some customers without affecting their overall profitability, making compensation unnecessary" and that "it would be premature to speculate on any potential implications that may arise from any proposed policy changes affecting private health insurance" (DFAIT 2005). Again, these comforting conclusions were all reached prior to the Chaoulli decision. The principal issue now is not how much the development of a private insurance market could prevent expansion of medicare, but whether medicare's current monopoly on single-payer insurance can continue to be protected. It is no longer premature, but indeed necessary, to consider how much foreign penetration of the Canadian market, when combined with lifting the ban on private insurance, could result in a combination of potential NAFTA financial compensation to private investors and GATS compensation in the form of trade concessions to WTO member governments that would make reversing market-based changes difficult.

\section{Conclusion}

If, as a result of the Chaoulli decision, the stage is set for the introduction of parallel private coverage for services currently covered by the public system, there will be an interesting debate in Canada about whether Parliament and provincial legislatures should use the "notwithstanding" clause. But as long as Chaoulli does not lead to the creation of a full-blown, two-tier health system in Quebec and across Canada, it should serve as a salutary "shot across the bow" that not only galvanizes governments to shorten waiting lists, but also to "trade-proof" their health policies.

First, in order to increase the chances that NAFTA reservations and the GATS exemption clause will apply to any given policy, a checklist of objective criteria likely to be used by NAFTA and WTO dispute panels should be kept in mind and assigned values in the cost-benefit analyses of policy options. These include: the extent of government regulation and control over delivery of the service; the degree to which the service is provided by not-for-profit organizations; the presence of competitive and commercial markets; and, perhaps most importantly, the degree of public versus private financing. 
Second, healthcare reforms can be structured to minimize the opportunities for US and Mexican investors to claim compensation under the expropriation provisions of chapters 11 and 12 of NAFTA. In order to accomplish this, however, the agnostic attitude of the Kirby Committee towards public versus private delivery of healthcare may need to be modified, and the benefits of expanded private financing promoted by the Mazankowski Commission will need to be reassessed. It is ironic that the two most influential advocates of greater competition and market-based reform of Canadian healthcare have not invested a commensurate amount of effort into investigating the trade treaty implications of their proposals (Grieshaber-Otto and Sinclair 2004).

On the policy front, it is noteworthy that in Canada's initial requests for GATS market access commitments in 2002, its initial conditional GATS offer in 2003 and its more recent revised offer, Canada has consistently maintained that it has preserved full policy flexibility with respect to health, public education and social services, while at the same time continuing to push for a more liberalized global market for financial services. A similar position is being taken with respect to the negotiations towards the Free Trade Area of the Americas (FTAA).

Canada has also been vigorously promoting its healthcare exports (which are currently worth about $\$ 5$ billion annually), especially in the areas of bio-health, medical devices, pharmaceuticals and telehealth, while avoiding them as subjects for trade negotiations, out of sensitivity to domestic concerns. None of these positions are necessarily inconsistent or wrong; indeed, they may well be wise. They should be accompanied by three caveats, however:

- Binding commitments to open markets to greater penetration by foreign service providers should always take into account the potential compensation costs that may be incurred should policy priorities or policy environments unexpectedly change.

- The classification of services for one purpose may have unintended and unforeseen consequences for other purposes.

- The separation between public and private financing of healthcare should never be assumed to be either clear or immutable.

In this regard, one measure could help to repair the firewall between private and public insurance that was damaged by Chaoulli, and thereby serve to restore and secure our domestic health policy space. Article XXI of GATS sets out the procedures for the withdrawal or modification of members' specific commitments. The member concerned must give at least three months' notice, and then negotiate compensatory adjustments with other countries whose trade interests have been affected, with the compensation applied on an MFN basis. (If an affected member is not satis- 
fied with the compensation offered, it can refer the matter to arbitration.) The ability of WTO members to withdraw their commitments has long been touted by the WTO Secretariat and member governments as a flexible feature of GATS. Canada should now put this claim to the test by withdrawing, or at least modifying, its 1997 commitment covering private health insurance. Whatever the cost or difficulty of such a procedure, we can be reasonably certain that it will never be purchased at a lower price.

Correspondence may be directed to: Mark Crawford, Department of Political Science, University of Northern British Columbia; email: mchammer@technologist.com.

\section{REFERENCES}

Chaoulli v. Québec (Attorney General), 2005 SCC 35.

Crawford, M. 2005."Truth or Consequences? The Law and Politics of the GATS Health Care Debate." Canadian Foreign Policy 12(2): 97-133.

Deber, R. 2002. Delivering Health Care Services: Public, Not-for-Profit, or Private? Discussion Paper No. 17. Ottawa: Commission on the Future of Health Care in Canada.

Department of Foreign Affairs and International Trade (DFAIT). 2005. Frequently Asked Questions about the Report. Retrieved December 1, 2005. <http://www.dfait-maeci.gc.ca/tna-nac/ TS/faq-report-en.asp>.

Epps, T. and C. Flood. 2002." Have We Traded Away the Opportunity for Innovative Health Care Reform? The Implications of the NAFTA for Medicare." McGill Law Journal 47: 747.

Epps, T. and D. Schneiderman. 2005. "Opening Medicare to Our Neighbours or Closing the Door on a Public System? International Trade Law Implications of Chaoulli v. Quebec." In C.M. Flood, K. Roach and L. Sossin, eds., Access to Care, Access to Justice: The Legal Debate Over Private Health Insurance. Toronto: University of Toronto Press.

Evans, R. 2003. Political Wolves and Economic Sheep: The Sustainability of Public Health Insurance in Canada. Vancouver: Centre for Health Services and Policy Research. Retrieved December 1, 2005. $<$ http://www.chspr.ubc.ca/chspr/pdf/chspr03-16W.pdf $>$.

Evans, R. 2005. “Preserving Privilege, Promoting Profit.” In C.M. Flood, K. Roach and L. Sossin, eds., Access to Care, Access to Justice: The Legal Debate Over Private Health Insurance. Toronto: University of Toronto Press.

Flood, C. and S. Lewis. 2005. “Courting Trouble: The Supreme Court's Embrace of Private Health Insurance." Healthcare Policy 1(1): 26-35.

Grieshaber-Otto, J. and S. Sinclair. 2004. Bad Medicine: Trade Treaties, Privatization and Health Care Reform in Canada. Ottawa: Canadian Centre for Policy Alternatives.

Krajewski, M. 2003. "Legal Services and Trade Liberalization: Mapping the Legal Framework.” Journal of International Economic Law 6(2): 341-367.

Sanger, M. 2001. Reckless Abandon: Canada, the GATS and the Future of Health Care. Ottawa: Canadian Centre for Policy Alternatives. 
Standing Committee on Social Affairs, Science and Technology ("Kirby Committee"). 2002. The Health of Canadians - The Federal Role. Final Report. Retrieved December 1, 2005. <http://www. parl.gc.ca/37/2/parlbus/commbus/senate/com-e/soci-e/rep-e/repoct02vol6-e.htm >.

Van Duzer, J.A. 2004a. “The Canadian Preoccupation with NAFTA's Impact on Health Services: A Serious Issue, a Non-Issue or Something in Between?” In K.C. Kennedy, ed., The First Decade of NAFTA: The Future of Free Trade in North America. New York: Transnational Publishers.

Van Duzer, J.A. 2004b. Health, Education and Social Services in Canada: The Impact of the GATS. Trade Policy Research 2004. Retrieved December 1, 2005. <http://www.dfait-maeci.gc.ca/eet/ research/TPR-2004/TPR-2004-10-en.asp\# ${ }^{*}$ d>.

\section{Research. Evidence. Dissemination.}

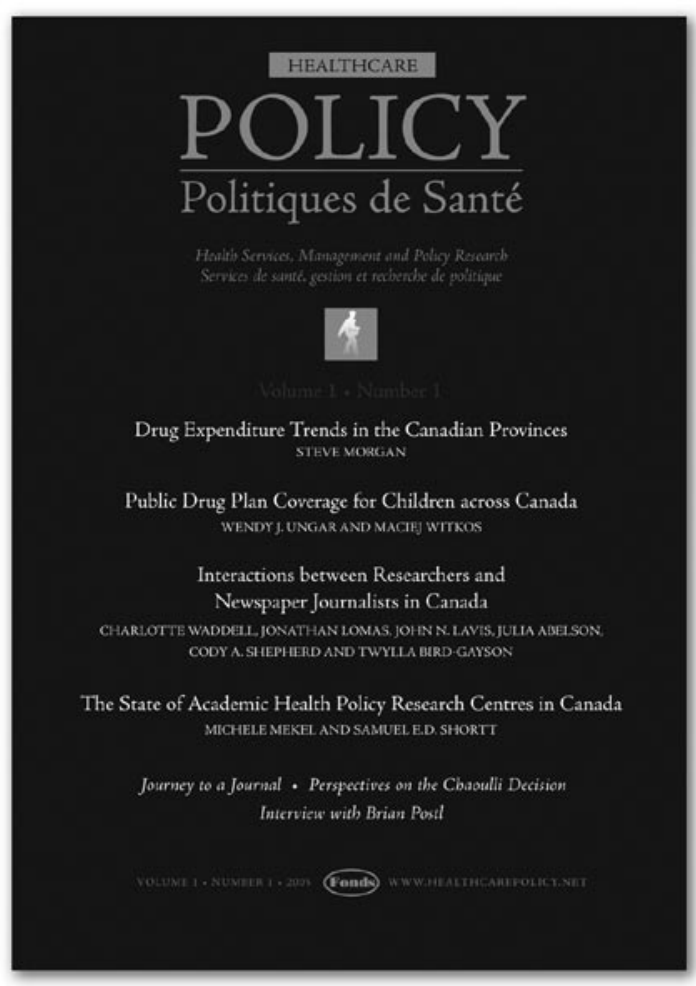

\section{www.healthcarepolicy.net}

